\title{
ANALISIS KOMPETENSI GURU KIMIA DALAM MENGIMPLEMENTASIKAN MODEL PEMBELAJARAN BERBASIS KURIKULUM 2013 DI SMK SMAK MAKASSAR
}

\author{
Asniati, Mansyur' ${ }^{1}$, Tabrani Gani \\ ${ }^{1,2}$ Dosen Program Pascasarjana Universitas Negeri Makassar \\ Email: nhiasweet20@gmail.com
}

\begin{abstract}
ABSTRAK
Jenis penelitian ini adalah penelitian deskriptif dengan pendekatan kualitatif. Penelitian ini bertujuan untuk mengetahui; (i) gambaran pelaksanaan standar kompetensi guru dalam menerapkan model pembelajaran berbasis kurikulum 2013 di SMK-SMAK Makassar; (ii) gambaran penerapan model pembelajaran kurikulum 2013 oleh guru pada proses pembelajaran kimia di SMK-SMAK Makassar. Metode pengumpulan data melalui observasi setiap pertemuan di kelas; wawancara dan dokumentasi berupa catatan kecil dan rekaman video. Hasil penelitian ini menunjukan bahwa; (i) gambaran penerapan standar kompetensi guru dalam menerapkan model pembelajaran kurikulum 2013 di SMK-SMAK Makassar menunjukan kriteria kompetensi sangat kompeten; pada kriteria kompetensi sangat kompeten dengan mengedepankan aspek-aspek kompetensi guru profesional, sedangkan (ii) gambaran pengamatan implementasi model pembelajaran kurikulum 2013 pada saat proses pembelajaran kimia di SMK-SMAK Makassar menunjukan kategori keterlaksanaan sangat baik.
\end{abstract}

Kata kunci: Implementasi, Standar Kompetensi Guru, Model Pembelajaran Kurikulum 2013

\begin{abstract}
The research is descriptive research with qualitative approach. The research aims to discover: (i) the description of the implementation of teachers' competence standards in implementing learning model based on 2013 curriculum in SMK-SMAK Makassar; (ii) the description of the implementation of learning model based on 2013 curriculum in chemistry learning process in SMK-SMAK Makassar. The method of collected through observation in each meeting in classroom, interview, and documentation in forms of small note and video recording. The results of the research reveal that: (i) the description of the implementation of teachers's competence standards in implementing learning model based on curriculum 2013 in SMKSMAK Makassar shows is in very competent criteria by high lighting professional teacher competence aspect, (ii) the description of the observation of the implementation of learning model based on 2013 curriculum in chemistry learning process in SMK-SMAK Makassar shows is in very good implementation category.
\end{abstract}

Keywords: Implementation, Teachers Competence Standards, Learning Model Based on Curriculum 2013 


\section{PENDAHULUAN}

Pendidikan merupakan unsur utama dalam pengembangan manusia Indonesia seutuhnya. Oleh karena itu pengelolaan pendidikan harus berorientasi kepada perubahan yang lebih baik. Kurikulum merupakan perangkat pendidikan yang diperlukan untuk mencapai tujuan yang telah ditetapkan. Kurikulum disusun dengan memperhatikan potensi, tingkat perkembangan, minat, kecerdasan intelektual, emosional, sosial, spiritual dan kinestika peserta didik (Mendikbud, 2013).

Berdasarkan perkembangannya, pemerintah indonesia dengan giat menyusun dan mengembangkan program untuk meningkatkan mutu pendidikan, salah satu diantaranya dengan penyempurnaan kurikulum. Perubahan kurikulum sangat erat kaitannya dengan peranan kurikulum dalam penyelenggaraan sistem pengajaran nasional.

Kurikulum 2013 yaitu kurikulum berbasis kompetensi dan karakter secara terpadu yang merupakan penyempurnaan dari Kurikulum Tingkat Satuan Pendidikan (KTSP). Menurut Hidayat (2013), Kurikulum 2013 merupakan program pendidikan yang berbeda dengan kurikulum 2013, perbedaan tersebut dapat dilihat dari segi karakteristik, pendekatan saintifik dan penilaian otentik dalam pembelajaran. Implementasi kurikulum 2013 mencakup tiga kegiatan pokok yakni pengembangan program, pelaksanaan pembelajaran, dan evaluasi.

$$
\text { Penerapan Kurikulum }
$$

berpengaruh terhadap orientasi sistem pembelajaran. Menurut Hosnan (2014), Berdasarkan Kurikulum 2013 kompetensi diklasifikasikan menjadi dua, yaitu Kompetensi Inti (KI) dan Kompetensi Dasar (KD). Kompetensi Inti mencakup KI-1 (sikap spiritual), KI-2 (sikap sosial), KI-3 (pengetahuan), dan KI-4 (keterampilan). Implementasi Kurikulum 2013 juga dipastikan memiliki dampak terhadap sistem penilaian, khususnya penilaian oleh pendidik dan satuan pendidikan. Kurikulum 2013 memiliki kebijakan yang harus dilaksanakan dan diselesaikan dengan sebaik-baiknya oleh guru, sebagai bagian dari tanggung jawab. Jika sebelumnya guru berfungsi sebagai sumber utama pengetahuan, mengendalikan, dan mengarahkan, serta perannya mengajar dikelas maka dalam konteks Kurikulum 2013 guru berperan sebagai fasilitator pembelajaran, pelatih, dan memberikan lebih banyak alternatif.

Kesiapan guru dalam proses implementasi Kurikulum 2013 memegang peranan penting dimana guru memiliki peran dan fungsi dalam membentuk kepribadian anak, guna menyiapkan dan mengembangkan sumber daya manusia (SDM) untuk mensejahterakan masyarakat, serta kemajuan bangsa dan negara. Keberhasilan tujuan pendidikan sangat bergantung pada kontribusi kinerja guru.

Guru merupakan salah satu komponen yang merupakan bagian yang tidak terpisahkan dari sistem pendidikan secara keseluruhan yang terlibat langsung dalam proses belajar mengajar, berperan langsung dalam mengajar dan mendidik. Guru diharapkan melaksanakan pembelajaran dengan pendekatan scentific dalam pembelajaran yang diperkuat dengan menerapkan model pembelajaran kurikulum 2013 diantaranya pembelajaran discovery, pembelajaran Inqury, pembelajaran berbasis pemecahan masalah (problem based learning) dan pembelajaran berbasis proyek (project based learning). Model-model pembelajaran kurikulum 2013 yang merupakan pembelajaran berbasis masalah paling sesuai dilaksanakan dan sangat direkomendasikan untuk dilaksanakan oleh para guru pada proses pembelajaran (Kemendikbud, Buku Panduan PLPG 2016).

Penguatan proses pembelajaran dilakukan melalui pendekatan saintifik, yaitu pembelajaran yang mendorong siswa lebih mampu dalam mengamati, menanya, mencoba, mengumpulkan data, dan mengomunikasikan. Sedangkan model pembelajaran diperlukan untuk berkembangnya kemampuan berpikir ilmiah dan kemampuan berfikir kreatif siswa, serta menghasilkan kemampuan untuk belajar. 
Pembelajaran saintifik tidak hanya memandang hasil belajar sebagai proses akhir, namun proses pembelajaran dipandang lebih penting. Oleh karena itu pembelajaran saintifik menekankan pada keterampilan proses (Kurinasih,2014)

Guru merupakan tenaga profesional yang harus memiliki kompetensi yang diperlukan sesuai dengan bidangnya khususnya guru Kimia. Kompetensi yang harus dimiliki oleh seorang guru meliputi empat aspek yaitu kompetensi pedagogik, kompetensi kepribadian, kompetensi sosial, dan kompetensi Profesional (Susilo, 2014). Kompetensi guru harus terus ditingkatkan untuk merespon kebutuhan peningkatan kualitas pendidikan yang akan menentukan kualitas proses pembelajaran yang selanjutnya akan berpengaruh pada kualitas hasil belajar yang menyangkut pengimplementasian guru dalam penerapan model pembelajaran kurikulum 2013.

Permasalahan guru dalam penerapan implementasi kurikulum 2013 menurut pemerhati pendidikan Universitas Negeri Surakarta Furqan Hidayatullah, berdasarkan hasil survei menyatakan bahwa betapa sulitnya mengubah mindset guru, dimana perubahan proses pembelajaran dari pembelajaran yang berpusat pada guru ke pembelajaran yang berpusat pada siswa (Ferdinandus dalam harian metrotvvews.com, Rabu 19 Oktober 2014). Kurikulum 2013 menuntut guru untuk menjadi lebih kreatif dan inovatif yang artinya guru harus menjadi manusia pembelajar, maka dari permasalahan tersebut dapat dikatakan pentingnya posisi guru dalam proses belajar mengajar sehingga kita perlu melakukan penelitian lebih lanjut terkait penerapan kurikulum 2013 khususnya pada implementasi model pembelajaran yang berbasis kurikulum 2013.

Selain itu, Berdasarkan hasil penelitian Riana dkk (2014), keberhasilan guru dalam mengimplementasikan Kurikulum 2013, yaitu $90 \%$ perangkat pembelajaran yang disusun oleh guru dan sudah baik sesuai dengan pedoman Kurikulum 2013 terbukti dari hasil supervisi yang dilakukan oleh Dinas Pendidikan, RPP yang disusun oleh guru telah diterapkan pada proses pembelajaran walaupun ada sedikit penyimpangan atau pengembangan saat proses pembelajaran berlangsung, siswa menjadi lebih kreatif dan lebih aktif dalam belajar, hasil belajar siswa lebih baik dan siswa telah memperoleh nilai diatas Kriteria Ketuntasan Minimum (KKM) lebih banyak.

Salah satu jenjang pendidikan yang menerapkan kurikulum 2013 adalah Sekolah Menengah Kejuruan (SMK), SMK memiliki peran penting dalam mengatasi masalahmasalah yang dihadapi oleh bangsa khususnya masalah terkait mutu sumber daya manusia. Pendidikan kejuruan yang diterapkan di SMK dirancang untuk memberikan penguatan pengetahuan peserta didik (ranah kognitif), mengembangkan keterampilan dan kecakapan sesuai dengan kompetensi keahlian masing-masing peserta didik (ranah psikomotorik), memberikan pendidikan karakter (ranah afektif), menumbuhkan kebiasan-kebiasan kerja kepada peserta didik, dan mempersiapkan peserta didik untuk siap memasuki lapangan kerja. Menurut Hamalik (2011) tujuan pendidikan kejuruan memiliki empat aspek dalam mempersiapkan peserta didik atau tamatannya untuk memasuki lapangan kerja serta dapat mengembangkan sikap profesional, mampu memilih karier, mempunyai kompetensi, mampu mengembangkan diri, menjadi tenaga kerja tingkat menengah untuk mengisi kebutuhan usaha dan industri pada saat ini maupun di masa yang akan datang serta menjadi warga negara yang produktif, adaptif dan kreatif.

Penelitian dilaksanakan di SMKSMAK Makassar karena SMK-SMAK merupakan satu-satu nya sekolah yang mengajarakan kompetensi keahlian dalam bidang analisis, dan termasuk sekolah yang dari awal telah menerapkan kurikulum 2013 yang merupakan rujukan langsung dari kementrian pendidikan nasional dimana semua guru SMK-SMAK telah mendapatkan pelatihan implementasi kurikulum 2013; serta melihat bagaimana cara penerapan kurikulum 2013 pada pembelajaran kimia khususnya pembelajaran teori. Selain itu, SMK-SMAK 
Makassar juga menjamin mutu kompetensi lulusan yang sesuai dengan kebutuhan dunia industri dan usaha, sekaligus merupakan salah satu sasaran reposisi pendidikan di lingkungan Kementrian Perindustrian yang telah berhasil meluluskan tenaga analisis kimia sebanyak 3.350 orang dan telah mengabdi diberbagai institusi baik di pemerintahan maupun diperusahaan swasta. SMK-SMAK Makassar memiliki Sertifikat lisensi dari Badan Nasional Sertifikasi Profesi (BNSP) Nomor BNSP-LSP-127-ID tanggal 23 Juli 2014 maka SMK-SMAK Makassar melalui lembaga Sertifikasi Profesi pihak Pertama (LSP-P1) Analisis Kimia dapat memberi sertifikat kompetensi kepada peserta didik selain itu SMK-SMAK Makassar telah melakukan kerjasama industri/instansi baik didalam maupun diluar Negeri (sumber: Bagian Kurikulum SMK-SMAK Makassar).

Oleh karena itu, peneliti melakukan penelitian tentang evaluasi kemampuan guru kimia dalam mengimplementasikan model pembelajaran berbasis kurikulum 2013. Maka dari itu, akan dilakukan penelitian "Analisis Kompetensi Guru Kimia Dalam Mengimplementasikan Model Pembelajaran Berbasis Kurikulum 2013 Di SMK-SMAK Makassar".

\section{METODE PENELITIAN}

Penelitian ini dilaksanakan di SMK-
SMAK Makassar yang telah
mengimplementasikan kurikulum 2013.
Penelitian ini merupakan penelitian deskriptif
dengan pendekatan kualitatif yang bertujuan
untuk menganalisis kompetensi guru dalam
mengimplementasikan model pembelajaran
kurikulum 2013. Pelaksanaan penelitian ini
dilaksanakan pada tanggal 20 Januari hingga
tanggal 20 Maret 2017.

Untuk memperoleh informasi tentang penerapan standar kompetensi dan implementasi model pembelajaran kurikulum 2013, maka digunakan instrumen penelitian berupa catatan seluruh kegiatan pembelajaran aktivitas guru dalam proses pembelajaran. Dalam hal ini observer yang akan mengumpulkan data secara langsung melalui pengamatan, antara lain :

\section{Lembar Observasi}

Lembar observasi disusun untuk memperoleh data lapangan tentang gambaran pelaksanaan standar kompetensi guru dan penerapan model pembelajaran kurikulum 2013 dengan melampirkan lembar rencana pelaksanaan pembelajaran (RPP) oleh guru sebagai acuan dalam pelaksanaan pembelajaran.

\section{Wawancara}

Teknik wawancara yang digunakan dalam penelitian ini sifatnya terstruktur yang bertujuan untuk mengetahui hal-hal tentang model pembelajaran kurikulum 2013 yang diketahui oleh subjek penelitian.

Teknik pengumpulan data merupakan suatu cara dalam pengambilan suatu kesimpulan yang diperlukan. Maka dari itu, teknik pengumpulan data yang digunakan berdasarkan instrument penelitian yaitu:

\section{Observasi}

Teknik observasi dilakukan oleh peneliti untuk mengamati dan mencatat semua aktivitas pelaksanaan standar kompetensi guru dan penerapan model pembelajaran kurikulum 2103 pada saat kegiatan pembelajaran berlangsung. Setiap aktivitas pelaksanaan standar kompetensi guru dan penerapan model pembelajaran kurikulum 2103 diamati melalui format observasi dengan mencentang atau memberi tanda $(\sqrt{ })$.

2. Wawancara

Teknik wawancara yang digunakan dalam penelitian ini sifatnya terstruktur dengan menggunaka pedoman wawancara untuk mengumpulkan data penelitian yang lebih mendalam tentang tujuan pertanyaan yang ditanyakan, serta kemungkinan lain yang muncul dari dampak pertanyaan yang diajukan berdasarkan fakta yang terjadi. Wawancara dilakukan setelah guru melaksanakan proses pembelajaran kimia.

\section{Dokumentasi}

Untuk mendukung data penelitian observer juga melakukan dokumentasi berupa rekaman video yang merekam seluruh 
aktivitas belajar mulai dari pembukaan sampai penutup pembelajaran.

Analisis data yang digunakan dalam penelitian ini yaitu aktivitas analisis data kualitatif yang dilakukan secara interaktif dan berlangsung secara terus menerus. Aktifitas dalam analisis kualitatif ada tiga yaitu tahap reduksi data, penyajian data, dan kesimpulan atau verifikasi. Adapun langkah-langkah analisis kualitatif sebagai berikut:

1. Reduksi data (data reduction)

Data yang diperoleh dari lapangan jumlahnya cukup banyak berupa lembar observasi pelaksananaan standar kompetensi guru, penerapan model pembelajaran discovery learning; data wawancara dan dokumentasi berupa rekaman video pada saat proses pembelajaran berlangsung, untuk itu maka perlu dicatat secara teliti dan rinci. Mereduksi data berarti merangkum, memilih hal-hal yang pokok, memfokuskan pada hal-hal yang penting, dicari tema dan polanya dan membuang yang tidak perlu. Dengan demikian data yang telah direduksi akan memberikan gambaran yang lebih jelas, dan mempermudah peneiliti untuk melakukan pengumpulan data selanjutnya, dan mencarinya bila diperlukan.

2. Penyajian data (display data)

Setelah data direduksi, maka langkah selanjutnya adalah mendisplaykan data. Dalam penelitian kualitatif, penyajian data bisa dilakukan dalam bentuk uraian singkat, bagan, hubungan antar kategori dan sejenisnya.

3. Penarikan kesimpulan dan verifikasi (conclusion drawing/verification)

Kesimpulan awal yang dikemukakan masih bersifat sementara, dan akan berubah bila tidak ditemukan bukti-bukti yang kuat dan mendukung pada tahap pengumpulan data berikutnya. Apabila kesimpulan yang dikemukakan pada tahap awal, didukung oleh bukti-bukti yang valid dan konsisten, maka kesimpulan yang dikemukakan merupakan kesimpulan yang kredibel.
Kesimpulan dalam penelitian kualitatif yang diharapkan adalah merupakan temuan baru yang sebelumnya belum pernah ada. (Sugiyono, 2014)

Selain itu, Data pelaksanaan standar kompetensi guru dan penerapan model pembelajaran kurikulum 2013 dianalisis dengan menggunakan rubrik penilaian pada Tabel 3.1:

Tabel 3.1. Rubrik penilaian pelaksanaan standar kompetensi guru dan penerapan model pembelajaran kurikulum 2013

\begin{tabular}{|l|c|}
\hline \multicolumn{1}{|c|}{ Indikator Oprasional } & Skor \\
\hline $\begin{array}{l}\text { Selalu, apabila selalu melakukan sesuai } \\
\text { dengan pernyataan }\end{array}$ & 4 \\
\hline $\begin{array}{l}\text { Sering, apabila sering melakukan sesuai } \\
\text { pernyataan dan kadang-kadang tidak } \\
\text { melakukan }\end{array}$ & 3 \\
\hline $\begin{array}{l}\text { Kadang-kadang, apabila kadang-kadang } \\
\text { melakukan dan sering tidak melakukan }\end{array}$ & 2 \\
\hline $\begin{array}{l}\text { Tidak pernah, apabila tidak pernah } \\
\text { melakukan }\end{array}$ & 1 \\
\hline
\end{tabular}

Keterangan: Data berdasarkan pedoman penilaian yang telah di buat.

Setelah diperoleh hasil data pelaksanaan standar kompetensi guru dan penerapan model pembelajaran kurikulum 2013 selanjutnya dianalisis secara deskriptif dengan kriteria sebagai berikut:

\section{Standar Kompetensi Guru}

Data yang diperoleh dari hasil pengamatan pelaksanaan standar kompetensi guru dalam pelaksanaan pembelajaran maka yang dilakukan oleh seorang observer yaitu menganalisis dan mendeskripsikan dengan merujuk pada penentuan kriteria kompetensi (dimodifikasi dari Nurdin, 2007).

Tabel 3.2 Pelaksanaan kriteria standar kompetensi guru:

\begin{tabular}{|c|c|}
\hline Rentang Skor & Kriteria Kompetensi \\
\hline $3,5 \leq M \leq 4$ & $\begin{array}{l}\text { Sangat Kompeten } \\
\text { Kompeten }\end{array}$ \\
$2,5 \leq M<3,5$ & Kurang Kompeten \\
$1,5 \leq M<2,5$ & Tidak Kompeten \\
& \\
$M<1,5$ & \\
\hline
\end{tabular}

Keterangan: $\mathrm{M}=$ skor rata-rata keterlaksanaan standar kompetensi. 
Berdasarkan kriteria diatas maka untuk menyatakan penerapan standar kompetensi yang memadai adalah nilai rata-rata kriteria kompeten untuk keseluruhan aspek minimal berada pada kategori kompeten atau sangat kompeten untuk setiap aspek. Jika tidak memenuhi kriteria tersebut, maka perlu dilakukan revisi berdasarkan saran dari para validator atau dengan melihat kembali aspekaspek yang nilainya kurang.

\section{Penerapan Model Pembelajaran Kurikulum 2013}

Data yang diperoleh dari hasil pengamatan penerapan model pembelajaran kurikulum 2013 yang dilakukan oleh pengamat (observer), dianalisis dan dideskripsikan dengan merujuk pada penentuan kategori keterlaksanaan model pembelajaran kurikulum 2013 dimodifikasi dari Nurdin (2007). Kategori tersebut dapat dilihat pada Tabel berikut.

Tabel. 3.3. Penerapan Model Pembelajaran Kurikulum 2013

\begin{tabular}{cc}
\hline Rentang Skor & $\begin{array}{c}\text { Kategori } \\
\text { Keterlaksanaan }\end{array}$ \\
\hline $3,5 \leq \bar{X} \leq 4$ & Sangat Baik \\
\hline $2,5 \leq \bar{X}<3,5$ & Baik \\
\hline $1,5 \leq \bar{X}<2,5$ & Cukup Baik \\
\hline $0,5 \leq \bar{X}<1,5$ & Kurang Baik \\
\hline
\end{tabular}

Keterangan: $\bar{X}=$ Nilai rata-rata penerapan model pembelajaran K13

Pelaksanaan penerapan model pembelajaran kurikulum 2103 dikatakan efektif jika rata-rata skor dari semua aspek yang dinilai berada pada kategori baik atau sangat baik.

\section{HASIL DAN PEMBAHASAN}

1. Hasil Penelitian

a. Gambaran Pelaksanaan Standar Kompetensi Guru

Pelaksanaan standar kompetensi guru selama penelitian berlangsung pada proses pembelajaran memperlihatkan kemampuan seorang guru dalam menerapkan aspek pengetahuan, keterampilan dan sikap yang dianut dalam pelaksanaan profesi sebagai guru. Standar kompetensi guru merupakan suatu ukuran yang ditetapkan sebagai bentuk kelayakan guru menjalankan tugasnya yang disesuaikan dengan latar belakang pendidikan sesuai bidang keahlian yang diampu.

Berdasarkan hasil pengamatan selama penelitian, pelaksanaan standar kompetensi guru terlaksana sesuai dengan standar kualifikasi akademik dan kompetensi guru. Adapun rincian setiap aspek kompetensi pada saat pengamatan yang berlangsung dalam proses pembelajaran pada Tabel 4.2.

Tabel 4.2 Hasil Observasi standar kompetensi guru pada proses pembelajaran

\begin{tabular}{|c|c|c|}
\hline $\begin{array}{c}\text { Aspek } \\
\text { Pengamatan }\end{array}$ & $\begin{array}{c}\text { Rata-rata } \\
\text { Total } \\
\text { Hasil } \\
\text { Pengamat } \\
\text { an }\end{array}$ & $\begin{array}{c}\text { Kriteria } \\
\text { Kompetensi }\end{array}$ \\
\hline $\begin{array}{c}\text { Kompetensi } \\
\text { Pedagogik }\end{array}$ & 3,4 & Sangat Kompeten \\
\hline $\begin{array}{c}\text { Kompetensi } \\
\text { Kepribadian }\end{array}$ & 3,7 & Sangat Kompeten \\
\hline $\begin{array}{c}\text { Kompetensi } \\
\text { Sosial }\end{array}$ & 3,7 & Sangat Kompeten \\
\hline $\begin{array}{c}\text { Kompetensi } \\
\text { Profesional }\end{array}$ & 3,6 & Sangat Kompeten \\
\hline Total Rata-rata & $\mathbf{3 , 6}$ & $\begin{array}{c}\text { Sangat } \\
\text { Kompeten }\end{array}$ \\
\hline
\end{tabular}

Sumber: Lampiran 5, Hasil Observasi Standar Kompetensi Guru

Berdasarkan Tabel 4.2 pengamatan pelaksanaan standar kompetensi guru dalam proses pembelajaran dikelas menunjukan total rata-rata pengamatan yaitu 3,6 diperoleh dari skala 0-4 dan jika dipresentasekan maka diperoleh $90 \%$ dan berada pada kriteria kompetensi sangat kompeten; sehingga dapat disimpulkan bahwa masing-masing guru telah melaksanakan profesi-nya sebagai guru yang sangat kompeten pada masing-masing bidang yang diampu dengan menerapkan penilaian kompetensi dalam proses pembelajaran sesuai Standar Kualifikasi Akademik dan Kompetensi Guru.

\section{b. Gambaran Penerapan Model Pembelajaran Kurikulum 2013}

Berdasarkan hasil pengamatan langsung pada saat proses pembelajaran, model pembelajaran yang digunakan pada penelitian ini yaitu model pembelajaran 
discovery learning; sebelum memulai pembelejaran terlebih dahulu guru merancang rancangan pembelajaran RPP sesuai dengan tuntutan kurikulum 2013 yang mencantumkan langkah-langkah pembelajaran untuk diterapkan serta menentukan model yang akan digunakan dalam pembelajaran yang disesuaikan dengan materi.

Penerapan model pembelajaran tidak lepas dari tahapan sintaks model pembelajaran discovery dengan menerapkan tahapan-tahapan 5M yakni, mengamati, menanya, mengumpulkan informasi, menganalisis informasi dan menarik kesimpulan. Setelah melakukan pengamatan selama 3 kali pertemuan oleh masing-masing subjek maka diperoleh hasil pengamatan gambaran penerapan model pembelajaran discovery pada Tabel 4.3.

Tabel 4.3 Hasil observasi penerapan model pembelajaran Discovery Learning dalam proses pembelajaran

\begin{tabular}{|l|c|c|}
\hline $\begin{array}{c}\text { Kegiatan } \\
\text { Pengamatan }\end{array}$ & $\begin{array}{c}\text { Rata-rata } \\
\text { Hasil } \\
\text { Pengamat } \\
\text { an }\end{array}$ & $\begin{array}{c}\text { Kategori } \\
\text { Keterlaksanaa } \\
\mathbf{n}\end{array}$ \\
\hline Subjek 1 & 3,5 & Sangat Baik \\
\hline Subjek 2 & 3,7 & Sangat Baik \\
\hline Subjek 3 & 3,6 & Sangat Baik \\
\hline Total Rata-rata & $\mathbf{3 , 6}$ & Sangat Baik \\
\hline
\end{tabular}

Sumber: Lampiran 5, Hasil Observasi Penerapan Model Discovery Learning

Berdasarkan hasil pengamatan pelaksanaan model pembelajaran pada saat pembelajaran berlangsung pada Tabel 4.3 menunjukan total rata-rata hasil pengamatan penerapan model pembelajaran adalah 3,6 yang diperoleh dari skala 0-4 dan jika dipresentasekan maka diperoleh nilai $90 \%$ dengan kategori keterlaksanaan sangat baik. Data yang diperoleh menunjukan kegiatan pelaksanaan model pembelajaran discovery dimana peserta didik belajar secara aktif dalam menemukan konsep, makna dari penggabungan pengetahuan baru dan pengetahuan yang sudah ada.

\section{Pembahasan}

Perubahan kurikulum tingkat satuan pendidikan menjadi kurikulum 2013 menyebabkan beberapa guru belum memahami maksud dari pada kurikulum 2013 dan cara mengimplementasikannya. Dimana diketahui bahwa guru memegang peranan penting dalam implementasi kurikulum 2013, guru diharapkan melaksanakan pembelajaran dengan pendekatan saintifik dengan menerapkan model pembelajaran yang telah direkomendasikan oleh pemerintah. Kompetensi guru merupakan faktor penting yang harus dimiliki seorang guru, diantaranya aspek pengetahuan, keterampilan, proses berfikir, penyesuaian diri, dan sikap. Standar kompetensi guru merupakan suatu ukuran yang ditetapkan atau dipersyaratkan dalam penerapan kurikulum 2013.

\section{a. Gambaran Pelaksanaan Standar Kompetensi Guru}

Berdasarkan hasil pengamatan selama beberapa pertemuan maka dapat disimpulkan bahwa standar kompetensi guru disekolah SMK-SMAK Makassar merupakan guru yang sangat kompeten yang memiliki kualifikasi akademik dibidangnya karna mengajar sesuai dengan latar belakang pendidikan yang diampu.

Pada saat proses pembelajaran berlangsung guru melaksanakan pembelajaran secara terstruktur dimana penyampaian materi dijelaskan secara lugas berdasarkan tahapan langkah-langkah pembelajaran yang telah dibuat sebelum memulai pembelajaran. Pengamatan yang telah dilakukan pada saat proses pembelajaran berlangsung menunjukan gambaran standar kompetensi guru berdasarkan aspek pengetahuan, keterampilan dan prilaku yang dimiliki oleh guru yang dapat mempengaruhi tercapainya tujuan pembelajaran dan pendidikan disekolah. Berdasarkan hasil pengamatan, maka dapat dilihat pelaksanaan kompetensi guru berdasarkan lampiran lembar observasi pelaksanaan standar kompetensi guru.

\section{b. Gambaran Penerapan Model Pembelajaran Kurikulum 2013}

Dalam penerapannya, ada empat model pembelajaran pada kurikulum 2013 yaitu pembelajaran discovery learning, pembelajaran Inquiry, pembelajaran berbasis pemecahan masalah (problem based 
learning) dan pembelajaran berbasis proyek (project based learning). Model pembelajaran sangat berpengaruh untuk menciptakan kegiatan pembelajaran yang efektif, sehingga guru dituntut harus bijak dalam menentukan model yang akan digunakan untuk suatu materi yang akan diajarkan.

Model pembelajaran discovery lebih sering diguanakan khusunya di SMK karena mata pelajaran di sekolah kejuruan termasuk kelompok mata pelajaran bidang keahlian yang cenderung pada penguasaan konsep atau prinsip, maka dari itu penerapan model discovery learning paling sering digunakan dalam kelas teori karna disesuaikan dengan kondisi dan materi yang diajarkan, yang dimana pada sekolah SMK-SMAK Makassar merupakan sekolah kejuruan analisis kimia dimana kelas teori dan laboratorium dipisahkan dalam proses pembelajarannya.

Berdasarkan hasil pengamatan, hampir semua komponen terpenuhi dalam pembelajaran berdasakan tahapan-tahapan model pembelajaran discovery. Mulai dari kegiatan pendahuluan dimana guru memberikan gambaran melalui video, gambar ataupun dalam lingkungan sehari-hari yang memberikan motivasi kepada peserta didik dalam memulai proses belajar mengajar hingga pada kegiaatan inti yang menunjukan adanya aktivitas yang di dominasi oleh peserta didik dalam sebuah diskusi kelompok sehingga sebagian besar peserta didik menjadi aktif dalam memberikan respon pertanyaan kepada peserta didik lainnya. Pada akhir penutup pembelajaran guru mengarahkan peserta didik memberikan kesimpulan untuk masing-masing setiap kelompok serta memberikan tugas sesuai materi yang telah diajarkan dan tidak lupa guru mengarahkan peserta didik untuk mempelajari materi yang akan diajarkan pekan depan. Proses pembelajaran mendapat respon yang baik karena disesuaikan dengan kondisi dan karakteristik para peserta didik. Aktivitas peserta didik berlangsung efektif dimana peserta didik lebih aktif dalam merespon pembelajaran sehingga waktu dalam pelaksanaan pembelajaran untuk diskusi khususnya membutuhkan waktu yang lebih lama untuk menyelesaikannya sehingga dapat tercapai tujuan pembelajaran.

Setelah tahapan-tahapan pembelajaran terlaksana dengan baik, peneliti melakukan wawancara terhadap masing-masing subjek dengan tujuan mencari informasi yang berhubungan dengan pelaksanaan model pembelajaran berbasis kurikulum 2013 yang telah diterapkan dalam proses pembelajaran di kelas yang bertujuan paling efektif agar proses belajar mengajar berjalan dengan kondusif.

Berdasarkan hasil wawancara yang diperoleh dari guru SMK-SMAK Makassar setelah pengamatan standar kompetensi guru dengan melihat rancangan pelaksanaan pembelajaran serta penerapan model pembelajaran berbasis kurikulum 2013 maka dapat disimpulkan bahwa implementasi khususnya model pembelajaran berbasis kurikulum 2013 telah terlaksana dengan baik.

\section{KESIMPULAN}

1. Gambaran pelaksanaan standar kompetensi guru dalam proses pembelajaran dikelas menunjukan total rata-rata hasil pengamatan setiap subjek penelitian yaitu 3,6 pada kriteria kompetensi sangat kompeten, dimana masing-masing guru telah melaksanakan profesi-nya sebagai guru yang sangat kompeten pada bidang yang diampu dengan menerapkan penilaian kompetensi dalam proses pembelajaran sedangkan,

2. Gambaran pada tahap hasil pengamatan pelaksanaan model pembelajaran menunjukan total rata-rata hasil pengamatan penerapan model pembelajaran Discovery learning adalah 3,6 kategori keterlaksanaan sangat baik, dimana masing-masing guru melaksanakan sesuai dengan tahapan langkah-langkah pembelajaran Discovery learning dimana pada kegiatan pembelajaran peserta didik belajar secara aktif dalam menemukan konsep, makna dari pengetahuan sebelumnya kemudian 
menggabungkan pengetahuan baru dan pengetahuan yang sudah ada dan menerapkannya pada saat proses pembelajaran berlangsung.

\section{DAFTAR PUSTAKA}

Amien, M. 1987. Mengajarkan Ilmu Pengetahuan Alam (IPA) dengan Menggunakan Metode Discovery dan Inkuiry. Jakarta: Depdikbud.

Arifin, Z. 2016. Evaluasi Pembelajaran. Prinsip Teknik dan Prosedur. Bandung: PT Remaja Rosdakarya.

Azwar. S. 2015. Penyusunan Skala Psikologi. Yogyakarta: Pustaka Pelajar.

Agi, Ginanjar. 2015. Pengaruh Metode Inkuiri Terhadap Hasil Belajar Siswa SMP STKIP NU Indramayu. Jurnal Kependidikan, Volume 45, Nomor 2. Diakses 16 September 2016.

Bogdan, R.C \& Biklen, S.K. 1992. Qualitative Research in Education: An introduction to theory and Methods. Second Edition. Allyn and Bacon. Boston.

Buck, B.L., Bretz, S.L., dan Towns, M.H. 2008. Characterizing the level of inquiry in the undergraduate laboratory. Journal of College Science Teaching. Diakses 19 Juli 2016

Chang, R. 2005. KIMIA DASAR. KonsepKonsep Inti.Edisi ketiga. Jilid2. Jakarta : Erlangga

Depdikbud. 1993. Kurikulum Pendidikan Dasar GBPP Sekolah Lanjutan Tingkat Pertama. Jakarta: Depdikbud. Eggen, Paul D. \& Kauchak, Donald P. 1996. Strategis forn Teachers Teaching Content and Thinking Skill. Boston: Allyn and Bacon.

Evi, S. Bahriah, dan Sella, M, Abadi. 2016. Motivasi Belajar Siswa Pada Materi Ikatan Kimia Melalui Metode Praktikum. EduChemia Vol.1, No.1, Januari 2016 (Jurnal Kimia dan Pendidikan). Diakses 19 Juli 2016.

Fitria Rizkiana, I Wayan Dasna dan Siti Marfu'ah. 2016. Pengaruh praktikum dan demonstrasi dalam pembelajaran inkuiri terbimbing terhadap motivasi belajar siswa Pada materi asam basa ditinjau dari kemampuan awal. Pendidikan Kimia PascasarjanaUniversitas Negeri Malang. Jurnal Pendidikan: Teori, Penelitian, dan Pengembangan Volume: 1 Nomor: 3. Diakses 19 Juli 2016

Hermawati, N.W.M. 2012. Pengaruh Model Pembelajaran inkuiri Terhadap Penguasaan Konsep Biologi dan Sikap Ilmiah Siswa SMA Ditinjau Dari Minat Belajar Siswa, dari http:// pasca.undiksha.ac.id/ejournal/index. php/jurnal_ipa/. Diakses 19 juli 2016

Hussain, A., Azeem, M., dan Shakoor, A., 2011, Physic Teaching Methods: Scientific Inquiry vs Traditional Lecture, International Journal of Humanisties and Social Science, Vol 1, No 19, Diakses 19 Juli 2016

Hake, R. R. (2002c). Relationship of individual student normalized learning gains in mechanics with gender, high-school physics, and pretest scores on mathematics and spatial visualization. Retrieved on 3 March 2007 as reference 22 from <http://www.physics.indiana.edu/ ha ke>. Diakses 17 September 2016.

Iis Jahro Siti, 2010. "Analisis Penerapan Metode Praktikum Pada Pembelajaran Ilmu Kimia disekolah Menengah Atas"

http://isjd.pdii.lipi.go.id/admin/jurnal/ 41092934.pdf diakses 19 Juli 2016

Jensen, Eric. 2008. Pembelajaran BerbasisOtak. Indeks.Jakarta

Khan, M. dan Iqbal, M., 2010, Effect of Inquiry Lab Teaching Method on The Development of Scientific Skill Through The Teaching of Biology in Pakistan, Journal Strength for Today and Bright Hope for Tomorrow, Vol 11, No 1, Diakses 2 Oktober 2016

Kurniawan, Deni. 2011. Pembelajaran Terpadu. Bandung: Pustaka Cendikia Utama

Kamus Besar Bahasa Indonesia. 2012. Jakarta: PT. Gramedia Pustaka Utama. 
Khoirul Anam, M.A. 2015. Pembelajaran Berbasis Inkuiri Metode dan Aplikasi. Yogyakarta: Pustaka Pelajar

Nasar, Adrianus. 2011. Pendekatan Inkuiri Dalam pembelajaran sains. http://admin/jurnal /2011/02/ Diakses 4 September 2016

Nafisah, Hanim. Abdullah dan Khairil. 2015.

Penerapan Model Pembelajaran Inkuiri Terbimbing Berbasis Praktikum Pada Materi Sistem Ekskresi Untuk Meningkatkan Hasil Belajar Kognitif Peserta Didik Sma. Jurnal EduBio Tropika, Volume 3, Nomor 1. Diakses 19 Juli 2016

Mertiana, M.I.K. 2012. Pengaruh Implementasi Model Pembelajaran Inkuiri Terbimbing terhadap Peningkatan Motivasi Belajar dan Hasil Belajar IPA Yoseph I Denpasar Tahun Pelajaran 2011-2012, dari http://pasca.undiksha.ac.id/ejournal/index.php/jurnal_pendas/. Diakses 19 Juli 2016.

Oemar Hamalik. 2009. Proses Belajar Mengajar. Bumi aksara. Jakarta

Purba,M. 2007. Kimia 2 Untuk SMA Kelas XI. KTSP Standar isi 2006. Jakarta: Erlangga

Rustaman, 1996. Peranan Praktikum dalam Pendidikan Biologi. Makalah untuk penyuluhan pengelolaan praktikum Biologi LPTK FPMIPA IKIP Bandung.

Sardiman A.M., 2011. Interaksi dan Motivasi Belajar Mengajar. Jakarta: Rajagrafindo Persada.

Sugiono, 2009. Metode Penelitian. Bandung: Grapindo

Sudarmi. 2009. Model Pembelajaran Inkuiri Terbimbing Melalui Lab Riil Dan Virtuil Ditinjau Dari Gaya Belajar Dan Kemampuan Berpikir Abstrak. Tesis. PPs Pendidikan Fisika. Universitas Sebelas Maret, Surakarta. Diakses 19 Juli 2016

Syaiful Bahri Djamarah. 2011. Strategi Belajar Mengajar. Jakarta: Rineka Cipta.
Sanjaya, Wina. 2008. Kurikulum dan Pembelajaran: Teori dan Praktik Pengembangan. Jakarta: Kencana Prenada Media Group. 2012. Perencanaan dan Desain Sistem Pembelajaran. Jakarta :Fajar Interpratama Offset.

Sudjana, Nana dan Ahmad Rivai. 2001. Media Pengajaran. Bandung: Sinar Baru Algesindo.

Suparno, P. 2005. Miskonsepsi dan Perubahan Konsep dalam Pendidikan Fisika. Jakarta: Grasindo.

Subana, 2000. Statistik Pendidikan, Penerbit Pustaka Setia Bandung.

Trianto. 2010. Model-Model Pembelajaran Inovatif Berorientasi Kontruktivistik. Jakarta : Prestasi Pustaka

UU Sisdiknas. 2003. UndangUndangRepublik Indonesia Nomor 20 Tahu2003. http://www.unpad.ac.id/wpcontent/uploads/2012/10/UU20-2003

Sisdiknas.pdf. Diakses pada tanggal 17 September 2016. Ahmad. 1975. Menjadi Pimpinan Efektif. Jakarta: PT. Gramedia.

Anonim. 2013. Pembelajaran Kompetensi Smk Kurikulum 2013 Dengan Pendekatan Saintifik Dan Penilaian Autentik (Online). (http: //www.medukasi.web.id Media Pendidikan Indonesia, Diakses 17 November 2016)

Arifatud, Venissa, dan Rohmat. 2015. Implementasi Kurikulum 2013 pada perangkat Pembelajaran Model Discovery Learning Pendekatan Scientific Terhadap Kemampuan Komunikasi Matematis Materi Geometri SMK (Online). (http : //jurnal.unimus.ac.id JKPM, Volume 2 Nomor 1). Diakses Pada tanggal 3 Maret 2017

Ayu Nursholikhah. 2014. Analisis Kesiapan Guru Dalam Mengimplementasikan Kurikulum 2013 Pada Pembelajaran Matematika (Online). (http://eprints.ums.ac.id/28715/17/NA 
SKAH_PUBLIKASI, Diakses Pada tanggal 1 Desember 2016)

Boteach. S. 2006. 10 Conversations You Need To Have With Your Children. New York: Regan Books.

BSNP. 2006. Peraturan Pemerintah Nomor 19 Tahun 2005 tentang Standar Nasional Pendidikan. Jakarta.

Ferdinandus. 2014. Delapan Masalah Dalam Implementasi Kurikulum 2013 (Online). Harian Metrotvnews.com, Rabu 19 Oktober 2014. Diakses tanggal 5 Mei 2017.

Gardner. 2006. Teknik Mengembangkan Guru dan Siswa; Buku Panduan untuk Penilik Sekolah Dasar. Jakarta: Grasindo. Penerjemah: Setyani D. Sjah.

Hosnan. M. 2014. Pendekatan Saintifik dan Konstektual dalam pembelajaran abad 21. Bogor: Ghalia Indonesia

Hidayat. S. 2013. Pengembangan Kurikulum Baru. Bandung: PT. Remaja Rosdakarya

I Gusti Ngurah P, Nyoman Dantes, I Made Yudiana. 2013. Study Evaluatif Berbasis Model Centered, Input, Process, Productive Terhadap Pelaksanaan Pendidikan Sistem Ganda (PSG) Di SMK Mas Ubud Pada Jurusan Multimedia. E-journal Program Pascasarjana Universitas Pendidikan Ganesha

Jhon Helmi. 2014. Penilaian Autentik Dalam Kurikulum $2013 \quad$ (Online). (http://jurnalalishlah.word/2014, Diakses pada tanggal 4 April 2017)

Kemendikbud. 2013. Pengembangan Kurikulum 2013. Paparan Mendikbud dalam Sosialisasi Kurikulum 2013. Jakarta :Kemdikbud

Kemendikbud. 2016. Buku Panduan PLPG 2016 Materi Pedagogik. Paparan Mendikbud dalam Sosialisasi Kurikulum 2013. Jakarta :Kemendikbud

Kurinasih, I. Sani, B.2014. Sukses Mengimplikasikan Kurikulum 2013. Jogjakarta: Kata Pena.
Kosasi.E .2014. Strategi Belajar dan Pembelajaran (Implementasi Kurikulum 2013). Bandung: Yrama Widya

Kwartolo, Yuli. 2002. Catatan Kritis tentang Kurikulum Berbasis Kompetensi. Jurnal Pendidikan Penabur.

Musfah, Jejen. 2011.Peningkatan Kompetensi Guru. Jakarta: Kencana

Nurdin. 2007. Model Pembelajaran Matematika yang Menumbuhkan Kemampuan Metakognitif Untuk Menguasai Bahan Ajar. Disertasi. Surabaya: PPS UNS.

Pollard. 2005. Reflective Teaching. New York: Continuum.

Riana Nurmalasari, Reta Dian Purnama, dkk. 2014. Peran Guru Dalam Implementasi Kurikulum 2013 (Online). (Jurnal Program PascaSarjana Universitas Negeri Malang. Dikases pada tanggal 10 Desember 2016)

Ridwan, A. S. 2014. Inovasi Pembelajaran. Jakarta: Bumi Aksara

Suharno. 2014. Implementasi Pembelajaran Berbasis Kurikulum 2013 Pada Mata Pelajaran Biologi Di SMA Neg 1 Gondang Kabupaten Tulunggangung (Online). (Jurnal Humanity, ISSN 0216 - 8995. Diakses pada tanggal 9 Desember 2016)

Sugiyono. 2014. Metode Penelitian Kuantitatif Kualitatif dan $R \& D$. Bandung: Alfabeta.

Setianingsih, Nuning. 2015. Evaluasi Kesiapan Guru Kimia Dalam Implementasi Kurikulum 2013 Di Madrasah Aliyah Negeri Pilot Project DIY. Tesis Program Studi Pendidikan Sains

(Online). (http://eprints.uny.ac.id/25981/1/tesisnuning-setianingsih13708259010.swf, Diakses 15 Oktober 2016)

Surachman, Yuni dan suhardi. 2014. Implementasi Scientif Process Pada Mata Pelajaran Biologi Di MA Kotamadya Yogyakarta (Online). 
Jurusan Biologi FMIPA UNIY (Jurnal Pendidikan Matematika dan Sains Tahun II, No 2. Di akses 25 April 2017)

Susilo Nugroho. 2014. Kualifikasi Akademik dan Kompetensi Guru (Online). (http: //indo-

dinamis.blogspot.co.id/2013/04/kualif ikasi-akademik-kompetensi-

guru.html. Di akses tanggal 31 mei 2017)

Trianto. 2010. Mendesain Model Pembelajaran Inovatif - Progresif. Jakarta: PT Kencana Predana Media Grup

Vernianthy, Kanan Marinding. 2016. Profil Kemampuan Guru Mengimplementasikan Pendekatan Saintifik Dalam Pembelajaran Matematika. Tesis Program Studi Pendidikan Matematika. Universitas Negeri Makassar.

Yoko, Rimy. 2015. Implementasi Pendekatan Saintifik Dalam Pembelajaran IPA. Widyaiswara LPMP D.I Yogyakarta (Online). (http://lpmpjogja.org/wpcontent/uploads/2015/08/ImplementasiPendekatan-Saintifik-Dalam-

Pembelajaran-IPA1.pdf, Diakses: 25 Desember 2016) 